\title{
Effects of paraffine oil on leaf and berry mycobiota on two grape varieties
}

\author{
${ }^{1}$ Xénia Pálfi - ${ }^{1}$ Zoltán Karácsony - ${ }^{2}$ János Kátai - ${ }^{1}$ Zsolt Zsófi \\ ${ }^{1}$ Eszterházy Károly University Research Institute of Viticulture and Enology, Eger, Hungary \\ ${ }^{2}$ University of Debrecen Faculty of Agriculture-, Food Science and Environmental Managment, \\ Institute of Agrochemia and Pedology, Debrecen, Hungary \\ xpalfi@szbki-eger.hu
}

\begin{abstract}
SUMMARY
Application of fungicides have advantages and also some direct or indirect disadvantages, such as imbalance and/or fungicide resistance in microbe population. To avoid these problems the development of alternative, eco-friendly methods like mostly spraying with oils are in the focus nowadays. The investigations of the effects of fungicides on microbiota in some cultivations can give a more complex view to this topic and developmental possibilities. In the present study, our aim was testing of the effects of paraffine oil (as alternative fungicide) on microbial properties (CFU and rate of filamentous fungi and yeasts) of Chardonnay and Kékfrankos leaves and berries.

Our results from 2014 showed that the application of paraffine oil as sole spray agent can decrease the presence of saprophytic filamentous fungi on the berries of Chardonnay (susceptible for fungal infections). In the case of Kékfrankos berries opposite properties were observed, which may be the result of the absorption of oil by the thick wax layer of this variety. The oil treatment did not affect the yeast population of Chardonnay and Kékfrankos berries contrary to negative effect of the regular pesticide treatment. The selective fungicide effect of paraffine oil against filamentous fungal population caused the accumulation of yeast cells in the mycobiota of grape berries. The careful use of this yeasts in spontaneous fermentation can improve the aroma profile of wines. The year of 2015 did no prefer the growth of fungi, therefore no interesting properties were detected in the mycobiota of grape varieties. The occurence of the harmful saprophytic filamentous fungi predicted to be increased in mild climate agricultures as the result of the climate change.

In summary, the paraffine oils are seem to be promising tools for the eco-friendly control of harmful fungi of grapes.
\end{abstract}

Keywords: paraffine oil, mycobiota of grape leaf and berry, rate of filamentous fungi and yeasts

\section{ÖSSZEFOGLALASS}

A fungicidek alkalmazásának nyilvánvaló elönyei mellett vannak hátrányai is. Közvetve befolyásolja a mikroba populáció egyensúlyát, közvetlenül hozzájárul a fungicid rezisztens törzsek kialakulásához. Napjainkban ezen problémák elkerülése érdekében az alternativ, környezetkímélö módszerek fejlesztése áll a középpontban, mint például az olajjal történö permetezések. A fungicidek adott növény mikobiótájára kifejtett hatásának vizsgálata egy még komplexebb képet adhat a fejlesztési lehetöségekröl ebben a témában. Jelen tanulmány elkészitésével az volt a célunk, hogy a paraffinolajat fungicidként használva felmérjük annak hatását a Chardonnay és Kékfrankos szölöfajták leveleinek és bogyóinak mikrobiotájára. Vizsgáltuk a fonalasgombák és élesztök CFU értékeit és az egymáshoz viszonyitott megoszlását.

A 2014-es eredményeink azt mutatták, hogy a paraffinolajat önmagában alkalmazva csökkenhet a gombafertözésekre fogékonyabb terméssel rendelkezö Chardonnay fajta bogyóin a szaprofiton fonalas gombák jelenléte. Ezzel szemben ezt nem figyeltük meg a vastagabb bogyóhéjú Kékfrankos esetében. Ennek lehetséges oka, hogy a viaszréteg abszorbeálhatja a paraffinolajat. A hagyományos peszticid kezelés negativ hatásával szemben az olajkezelés nem befolyásolta a Chardonnay és Kékfrankos fajták bogyóinak élesztö-populációját. A paraffinolaj fonalasgombákkal szembeni szelektív hatása a szölöbogyók mikobiótájának, élesztöszámának fokozott növekedését okozta. Ezen élesztők körültekintö felhasználása a spontán fermentáció során gazdagithatja a borok aromaprofilját. A fitopatogén fonalas gombák jelenléte a mezögazdaságban jól láthatóan növekedik és várhatóan növekedni fog a mérsékelt éghajlati övben a klímaváltozás eredményeként.

Összegezve a tapasztalatokat, a paraffinolaj ígéretesnek tünhet a szölö káros fonalas gomba populációjának környezetkímélö szabályozásában.

Kulcsszavak: paraffinolaj, szölölevél és bogyó mikobióta, fonalas gombák és élesztők aránya

\section{INTRODUCTION}

Since the most dangerous fungal pathogens of grapevine, such as powdery mildew (PM) and downy mildew (DM) appeared and spreaded, fungicides were applied in grape cultivation. Beside their advantages some negative effects should be noticed. The increased and/or inefficient pesticide usage upsets the balance of soil and grape surface microbiota. This damage of microbial population is realised due to the destruction of soil quality (through chemical pollution and contamination) and development of microbial population with fungicide resistance (Miraglia et al., 2009). Nowadays increasingly emphasized the avoidance of these risks beside the preservation of fungicide effectiveness. There are alternative, eco-friendly methods to plant protection in the focus. Some survey also neccessary to investigate the effects of different pesticides to microbial population of grapevine (Sholberg et al., 2006). Hereby can reach a more complex view to this topic and developmental possibilities.

The microbial population of grapevine can be separated to consist of different type of microbes: Bacteria (Bacillus, Enterococcus, Enterobacter, Staphylococcus ssp. as environmental bacteria); Oomycetes, like Plasmopara viticola; true Fungi (parasitic filamentous fungi, yeastlike fungi and yeasts). It can be mentioned the so called Wine Microbial Consortium (WMC), in which members have role in the vinification processes. WMC microbes are yeasts, yeast-like fungi, acetic- and lactic acid bacteria. On the basis of several reports, this microbial 
population can be influenced by the climate conditions, the presence of nutrients and pesticides (Barata et al. 2012) or by the characteristics of vineyard and winemaking (Pretorius et al., 1999). The spraying against PM (or other infections in generally) affect negatively to the grape microbiota (Sholberg et al., 2006).

High precipitation causes high yeast colonization due to the higher availability of nutrients (Combina et al., 2005). Other examinations resulted in an opposite conclusion (Commitini and Ciani, 2006); or consider that warm, dry weather has a positive effect on yeast population (Rementeria et al., 2003). An other view was also reported, that weather conditions not affect yeasts (Jolly et al., 2003). In the case of pesticides the different reports are also contradictory. Intensive spraying due to the rainy weather cause an increased rate of oxidative yeasts (Longo, 1991; Čadež et al., 2010). Results by Viviani-Nauer et al. (1995) showed a general decrease of yeast population by the application of pesticides. In summary, the effects of environmental and human factors connect and depend on complex pathways.

\section{Characteristics of grape mycobiota}

The most important fungal pathogens of grapes are downy mildew (Plasmopara viticola) and powdery mildew (Erysiphe necator). Both obligate parasite contribute to reduction of canopy, therefore to the decrease of growth due to the declined leaf-assimilation (Moriondo et al., 2005). The PM often cause splitting of berries (Pearson and Goheen, 1998; Agrios, 2005), therefore the bunch become vulnerable to other microbiotic infections, such as the necrotrophic Botrytis cinerea (grey mould) and other saprophytic (Alternaria, Penicillium, Aspergillus, Cladosporium spp.) fungi (Tournas and Katsoudas, 2005; Aydogdu and Gucer, 2009). These microbes cause primary or secondary rotting of clusters and therefore decrease of yield and the quality of grape-juice.

Some typical post-harvest pathogens, such as $A s$ pergillus carbonatus and Aspergillus niger are able to produce mycotoxins, especially ochratoxin A (Pitt, 2000). Production of mycotoxins characteristic to the Penicillium spp. too at low temperature (Tournas and Katsoudas, 2005). Other saprophytic species (Alternaria, Cladosporium spp.) cause preferably allergy due to the huge amount of conidia. This intense growth helps to other mould contaminations (Tournas and Katsoudas, 2005). Therefore cool weather and delaying harvest is risky, rapid processing is necessary to avoid the mycotoxin accumulation. However it should be noted, that presence of saprophytic fungi as part of grape mycobiota is not relevant. The protection of plants against pathogens (E. necator, Botrytis cinerea) can reduce the risk of contamination by Aspergillus species (Hocking et al., 2007) among others.

The grape yeast mycobiota varies in time corresponding to phenological state (mostly between veraison and ripening until harvest) and possible injures of berries (Barata et al., 2012). The availability of nutrients (injure of berry or thin skin due to the ripening and damages by pests and infections) from berry is also influenced the type of colonizing yeasts. Yeasts of intact berry are mostly Basidiomycota and Aurebasidium pullulans (identified as yeast-like fungus) similar to leaf mycobiota. Berry injury shift the dominant yeast types from Basidiomycota to Ascomycota (weakly oxidative, than high fermentative) population. The presence of Botrytis, and powdery mildew are also change the yeast population (Gadoury et al., 2007; Barata et al., 2012).

Our aim was testing the effects of paraffine oil (as alternative fungicide) on microbial properties of grape leaves and berries. The rate of filamentous fungi and yeasts were also examined. This study didn't cover the exact identification of the isolates, the genera were defined only in the case of filamentous fungi. CorderoBueso et al. (2011) reported that yeast biodiversity of eco-friendly, organic vineyards is higher than in conventional fields. Oils used mostly in eco-friendly viticulture as insecticide and dormant sprays (Hofmann et al., 2008). The paraffine oil can be part of fungicide protection in integrated and ecological cultivation methods. There are more possibilities to apply mineral oils such as paraffine oil: 1) additives, 2) rotation partners among fungicides, 3) as dormant period sprayer (Janousek et al., 2009). Therefore it is rewarding to deal with examination of paraffine oil.

\section{MATERIAL AND METHODS}

The examined two grape varieties, Vitis vinifera $\mathrm{cv}$. Chardonnay and cv. Kékfrankos have different susceptibility to fungal infection. The Chardonnay is sensitive to combined infections due to the thin berry skin, mostly susceptible to PM. The Kékfrankos have thick berry skin, hence it less acceptable to cluster infections. In contrast, this grape variety have sensitive leaves to fungal pathogenes, such as PM and DM. Chardonnay leaves are less susceptible to these infections (Szőke, 1996; Bényei and Lőrincz, 2005).

The applied treatments of field trial in 2014-2015: regular treatment (CR), and two paraffine oil dosages: $2.2 \mathrm{v} / \mathrm{v} \%$ (T1) and $3.3 \mathrm{v} / \mathrm{v} \%$ (T2) without any other pesticides. The CR was the positive control (regular plant protection, applied pesticides depending on vintage characteristics). The fourth adjustment as negative control meaned no chemical plant protection (C0). These treatments were carried out in 3 replicates and buffer rows were applied to avoid overlapping of treatments in treated rows. In 2014, 7 sprayings have been executed and 8 sprayings in 2015 .

The leaf and berry samples of treatments (by 3 replicates each) were randomly selected and collected before harvest in the experimental years. Two leaf discs with $2.5 \mathrm{~cm}$ in diameter were vortexed in $3 \mathrm{ml}$ and 3 berries/sample were washed in $5 \mathrm{ml}$ steril distillated water. 50-50 $\mu \mathrm{l}$ from these suspensions were plated on DRB agar (Scharlau Chemie, S. A.) plates. The DRB is a selective medium developed for moulds and yeasts.

After a few days of incubation in a Binder (Binder $\mathrm{GmbH}$, Germany) incubator at $25^{\circ} \mathrm{C}$ the filamentous fungus and yeast colonies were counted. The colony numbers (colony forming units, CFUs) were referred to leaf surface $\left(\mathrm{cm}^{2}\right)$ and to berry weight $(\mathrm{g})$. The ratio between filamentous fungi and yeasts were also calculated. 
Data were analysed in GraphPad Prism 5. biostatistical program (GraphPad Software) demo version by OneWay Anova $(\mathrm{P}=0.05)$. Tukey Multiple Comparison post-tests were applied to calculate the presence of difference between two treatments; all pairs were compared to each other.

\section{RESULTS AND DISCUSSION}

Summary of vintage characteristics in 2014 and 2015

The meteorogical data were based on the database of Boreas Ltd. The examined years had different vintage characteristics. 2014 was somewhat cooler between May and August compared to the 50 years mean climatic data (1963-2013). The distribution of precipitation was changeable; the most rainy months were January, May and August-October period. The less precipitation was measured in March and June. The extreme rainfalls close to the harvest influence the quality and quantity of grapes negatively: 1) the harvest delayed due to the permanent rainfalls; 2) the contents of acides and aromes were diluted in grapes; 3 ) the intense fungal infections before harvest, such as $B$. cinerea and other pathogens (Alternaria spp.) caused big losses too. The year of 2014 was generally favourable to fungal infections.

In 2015, the weather was even dry and warm. Between June and September higher temperatures were measured than the 50 year means. The precipitation was also variable in that year. There were lower values than the 50 years mean data, except in January, March, and August to October. Only the August was extremely rainy opposite to the May and the July-September months of 2014. The year of 2015 was not favourable to the fungal infections.

Filamentous fungi on leaves and berries of Chardonnay and Kékfrankos

The most frequently observed filamentous fungi were related to Alternaria and Botrytis genera in both years on leaves and berries of both grape varieties. In some cases Aspergillus spp. were also found.

In 2014 significantly higher CFU values were detected in the case of $\mathrm{C} 0$ compared to $\mathrm{CR}$ and $\mathrm{T} 1$ treatments on Chardonnay leaf samples (Figure 1). The positive control was significantly lower than $\mathrm{T} 2$ and this phenomenon was characteristic to T1 and T2 too. CR and T1 treatments have not been differed significant. In the case of Chardonnay berries showed no significant differences among chemical treatments, except negative control. In the case of Kékfrankos leaf samples of all controls had significantly lower CFU values than oil treatments. $\mathrm{T} 1$ treatment had significantly higher filamentous fungi CFU on leaves than T2. In the case of Kékfrankos berries there were no significant differences.

In 2015 there were no significant differences observable (data not shown).

Figure 1: CFU values of filamentous fungi in the case of leaves and cluster samples of examined grape varieties in 2014

\section{Chardonnay leaf samples}

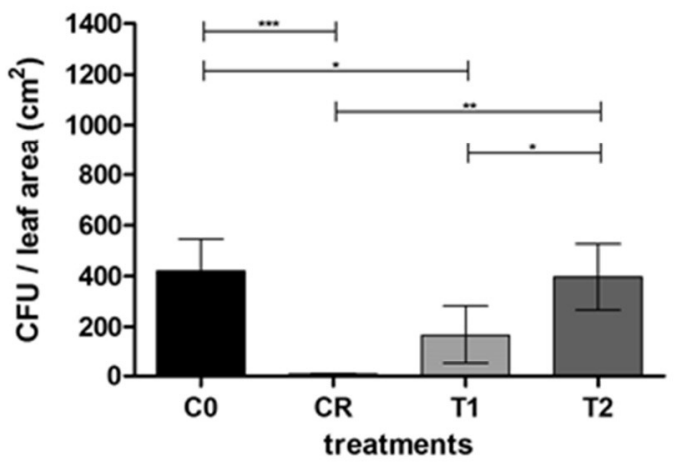

Chardonnay berry samples

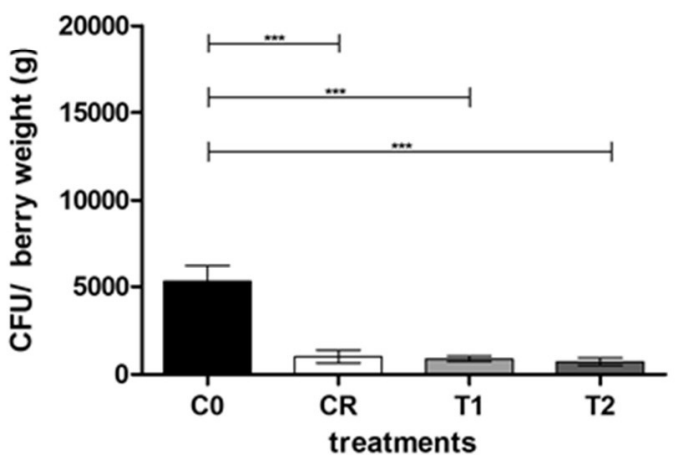

Kékfrankos leaf samples

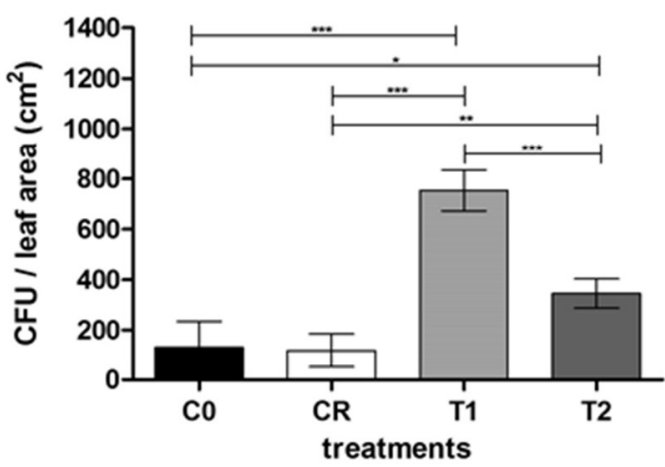

Kékfrankos berry samples

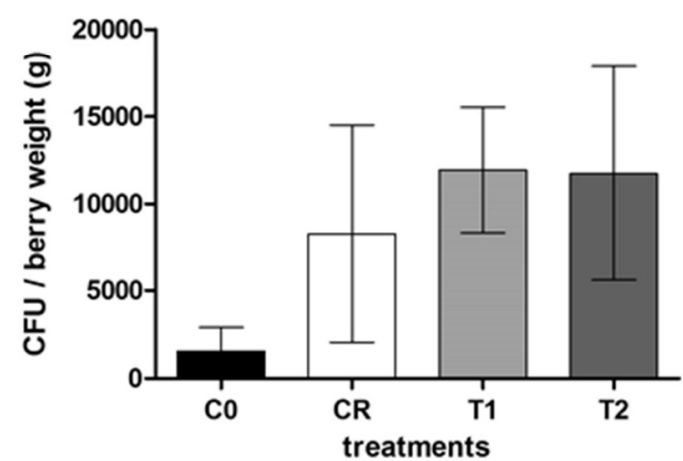

Note: Columns represent average CFU (colony forming unit) of replicates; they were referred to berryweight ( $\mathrm{g}$ ) in the case of clusters; to leaf area $\left(\mathrm{cm}^{2}\right)$ by leaf samples. Error bars show standard deviation. All significant properties are marked, meanings: $* \mathrm{p}<0.05, * * \mathrm{p}<0.005$, $* * * \mathrm{p}<0.0005$. 
Yeasts on leaves and berries of Chardonnay and Kékfrankos

The number of yeast colonies was between $10^{2}-10^{4}$ $\mathrm{CFU} / \mathrm{g}$ in both years, in accordance with Fleet et al. (2002). Yeast CFU on berries depend on berry properties: thin or thick skins (Li et al., 2010) and extent of surface (Renouf et al., 2005). Therefore there were differences in yeast population between grape varieties.

In 2014 leaf samples of Chardonnay showed significantly lower yeast CFU values in the case of CR and $\mathrm{T} 2$ treatment than $\mathrm{C} 0$ (Figure 2). CR had significantly lower yeast $\mathrm{CFU}$ value compared to $\mathrm{T} 1$. On berries of the Chardonnay white variety there were no significant differences among treatments. In the case of Kékfrankos leaves differed results were measured compared to Chardonnay. $\mathrm{C} 0$ had significantly lower CFU values than CR, but did not differ from oil treatments. CR had the highest yeast CFU, it also differed significantly from oil treatments. Between the controls of berry samples there were no difference detected. CR had significantly lower CFU values compared to oil treatments, which did not differ from each other.

In 2015 there were no significant differences among treatments (data not shown).

The rate of filamentous fungi and yeasts in the total fungal population

The rate of the two types of fungi on Chardonnay and Kékfrankos leaf and berry samples are presented in Table 1. In the year of 2014, the results of Chardonnay C0 (and T2 on leaves too) showed lower yeast population on leaf and berry samples than filamentous fungi. More filamentous fungi were detected on leaves than yeasts compared to CR. This phenomenon characteristic to the mycobiota of berry samples reciprocally. The $\mathrm{C} 0$ had the biggest filementous fungi population compared to chemical treatments, except in the case of leaves of $\mathrm{T} 2$ treatment. The rate of fungi on berry samples were dramatically less in the case of oil treatments and CR. In the case of Kékfrankos leaf samples the oil treatments increased the rate of filamentous fungi. Berry samples of red grape variety showed lower percentage of yeast under CR, as the biggest ones were under oil treatments.

The rate of filamentous fungi and yeasts were more balanced in 2015 than in 2014 (Table 1) in the case of both varieties and all samples. This phenomenon may due to the unfavourable weather conditions for the reproduction of fungi, which affected the fungi more than the different treatments.

\section{CONCLUSIONS}

As the part of eco-friendly disease control of grapes, alternative fungicide sprays (like paraffine oil) have an increasing significance. The expected properties of an agent for this purpose are to do not have any negative effect on the grapevine, on the product and on the useful organisms of vineyards, while effectively inhibiting the phytopathogenic organisms.

Figure 2: CFU values of yeasts in the case of leaves and cluster samples of examined grape varieties in 2014

Chardonnay leaf samples

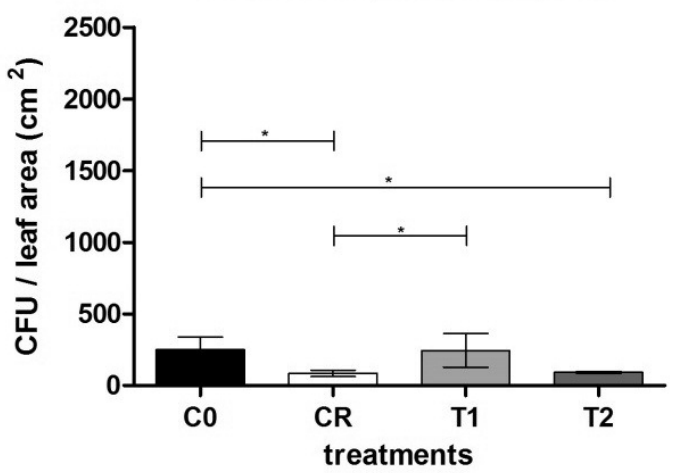

Chardonnay berry samples

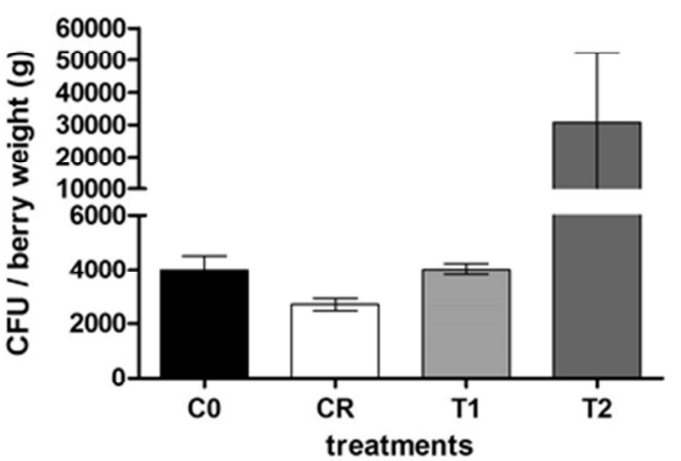

Kékfrankos leaf samples

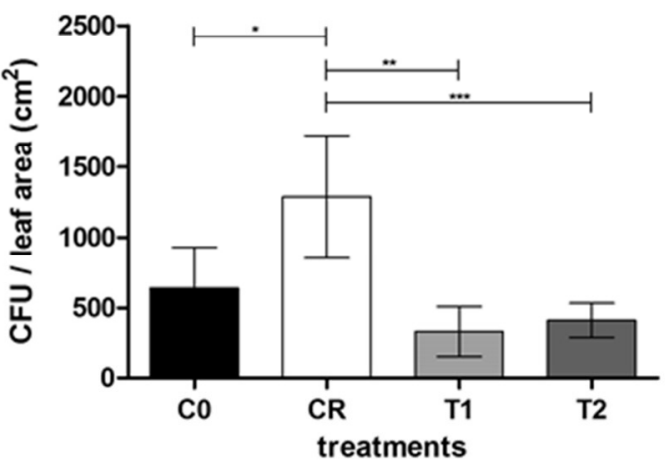

Kékfrankos berry samples

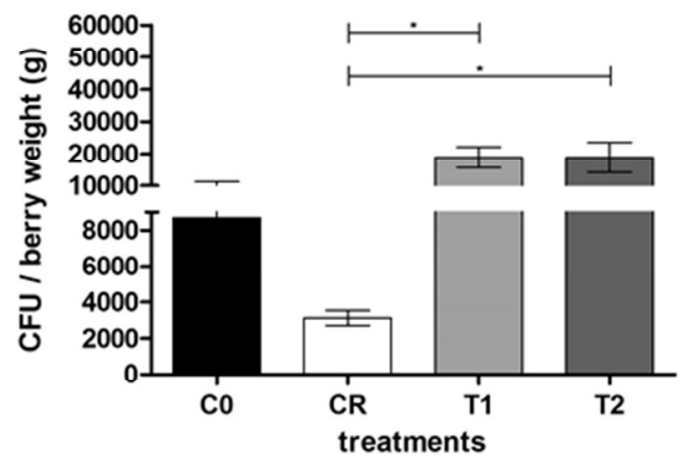

Note: columns represent average CFU (colony forming unit) of replicates; they were referred to berryweight ( $\mathrm{g}$ ) in the case of clusters; to leaf area $\left(\mathrm{cm}^{2}\right)$ by leaf samples. Error bars show standard deviation. All significant properties are marked, meanings: $* \mathrm{p}<0.05, * * \mathrm{p}<0.005$, $* * * \mathrm{p}<0.0005$. 
Rate of filamentous fungi (FF) and yeasts on leaf and berry samples of Chardonnay and Kékfrankos in 2014 and 2015

\begin{tabular}{|c|c|c|c|c|c|c|c|c|c|}
\hline & \multirow{4}{*}{ Treatments } & \multicolumn{4}{|c|}{ Chardonnay } & \multicolumn{4}{|c|}{ Kékfrankos } \\
\hline & & \multicolumn{8}{|c|}{2014} \\
\hline & & \multicolumn{2}{|c|}{ Leaf samples } & \multicolumn{2}{|c|}{ Berry samples } & \multicolumn{2}{|c|}{ Leaf samples } & \multicolumn{2}{|c|}{ Berry samples } \\
\hline & & $\mathrm{FF}(\%)$ & Yeast $(\%)$ & $\mathrm{FF}(\%)$ & Yeast $(\%)$ & $\mathrm{FF}(\%)$ & Yeast $(\%)$ & $\mathrm{FF}(\%)$ & Yeast (\%) \\
\hline $\mathrm{CO}$ & & 63 & 37 & 57 & 43 & 17 & 83 & 15 & 85 \\
\hline $\mathrm{CR}$ & & 8 & 92 & 28 & 78 & 8 & 92 & 73 & 27 \\
\hline $\mathrm{T} 1$ & & 40 & 60 & 18 & 82 & 46 & 54 & 38 & 62 \\
\hline \multirow{2}{*}{\multicolumn{2}{|c|}{$\mathrm{T} 2$}} & 81 & 19 & 2 & 98 & 69 & 31 & 39 & 61 \\
\hline & & \multicolumn{8}{|c|}{2015} \\
\hline $\mathrm{CO}$ & & 38 & 62 & 34 & 66 & 31 & 69 & 46 & 54 \\
\hline $\mathrm{CR}$ & & 30 & 70 & 49 & 51 & 38 & 62 & 36 & 64 \\
\hline $\mathrm{T} 1$ & & 39 & 61 & 31 & 69 & 37 & 63 & 34 & 66 \\
\hline $\mathrm{T} 2$ & & 53 & 47 & 59 & 41 & 33 & 67 & 40 & 60 \\
\hline
\end{tabular}

Note: table contains calculated data based on total CFU (yeast and filamentous fungi CFU). FF (\%) means filamentous fungi (\%).

Our results from 2014 showed that the application of paraffine oil as sole spray agent can decrease the presence of filamentous fungi on the berries of a grape variety with susceptible berries to fungal diseases (Chardonnay). This effect can not be observed in the case of Kékfrankos berries, which may be the result of the absorption of oil by the thick wax layer of this variety. The filamentous fungi of grape mycobiota can cause the rotting of damaged (mechanical injury, grey rot etc.) grapes and the accumulation of mycotoxins. The occurance of these filamentous fungi predicted to be increased in mild climate agricultures as the result of the climate change (Pautasso et al., 2012), therefore increasing of the risk of their negative effects.

On the other hand, the oil treatment did not affect the yeast population of Chardonnay and Kékfrankos berries contrary to the regular treatment. The selective fungicide effect of paraffine oil against filamentous fungal population caused the accumulation of yeast cells in the mycobiota of grape berries. The wild yeasts of the grape microbiota have a great impact on the wine production even in the case of controlled fermentation. In spontaneous fermentation, the optimal state of this wild yeast population is essential for the reliable production of good quality wines. This technique of wine production is not preferred nowadays, but has an increasing attention from some wine producers because of the increased aroma complexity (Romano et al., 2003).

In summary, the paraffine oils are seem to be promising tool for the eco-friendly control of pathogenic fungi of grapes.

\section{REFERENCES}

Agrios, G. N. (2005): Plant Pathology. $5^{\text {th }}$ edition. Elsevier Academic Press. 448-452.

Aydogdu, H.-Gucer, Y. (2009): Microfungi and mycotoxins of grapes and grape products. Trakia Journal of Sciences. 7. Suppl. 2: 211-214.

Barata, A.-Malfeito-Ferreira, M.-Loureiro, V. (2012): The microbia ecology of wine grape berries. A Review. International Journal of Food Microbiology. 153: 243-259.

Bényei F. - Lőrincz A. (szerk.) (2005): Borszőlőfajták, csemegeszőlő-fajták és alanyok. Fajtaismeret és -használat. Mezőgazda Kiadó. Budapest. 87-88, 107-108, 165-166.

Čadež, N.-Zupan, J.-Raspor, P. (2010): The effect of fungicides on yeast communities associated with grape berries. Fems Yeast Research. 10: 619-630.

Combina, M.--Mercado, L.-Borgo, P.-Elia, A.-Jofré, V.-Ganga, A.Martinez, C.-Catania, C. (2005): Yeasts associated to Malbec grape berries from Mendoza, Argentina. Journal of Applied Microbiology. 98: 1055-1061.

Comitini, F.-Ciani, M. (2006): Survival of inoculated Saccharomyces cerevisiae strain on wine grapes during two vintages. Letters in Applied Microbiology. 42: 248-253.

Cordero-Bueso, G.-Arroyo, T.-Serrano, A.-Tello, J.-Aporta, I.Vélez, M. D.-Valero, E. (2011): Influence of the farming system and vine variety on yeast communities associated with grape berries. International Journal of Food Microbiology. 145: $132-139$.
Fleet, G.-Prakitchaiwattana, C.-Beh, A.-Heard, G. (2002): The yeast ecology of wine grapes. [In: Ciani, M. (ed.) Biodiversity and Biotechnology of Wine Yeasts.] Research Signpost. Kerala. India. 1-17.

Gadoury, D. M.-Seem, R. C.-Wilcox, W. F.-Henick-Kling, T.Conterno, L.-Day, A.-Ficke, A. (2007): Effects of diffuse colonization of grape berries by Uncinula necator on bunch rots, berry microflora, and juice and wine quality. Phytopathology. 97: $1356-1365$.

Hofmann, U.-Paulin Köpfer, P.-Werner, A. (2008): Ökológiai szőlőtermesztés. Mezőgazda Kiadó. Budapest. 211-218, 230-236.

Hocking, A. D.-Leong, S. L.-Kazi, B. A.-Emmett, R. W.-Scott, E. S. (2007): Fungi and mycotoxins in vineyards and grape products.International Journal of Food Microbiology. 119: 84-88.

Janousek, C. N.-Bay, I. S.-Gubler, W. D. (2009): Control of grape powdery mildew with synthetic, biological, and organic fungicides: 2009 filed trials. Department of Plant Pathology. Univeristy of California. Davis. USA.

Jolly, N.-Augustyn, O.-Pretorius, I. (2003): The occurrence of nonSaccharomyces cerevisiae yeast species over three vintages in four vineyards and grapemusts fromfour production regions of theWestern Cape, South Africa. South African Journal of Enology and Viticulture. 24: 35-42. 
Li, S. S.-Cheng, C.-Li, Z.-Chen, J. Y.-Yan, B.-Han, B. Z.-Reeves, M. (2010): Yeast species associated with wine grapes in China. International Journal of Food Microbiology. 138: 85-90.

Longo, E.-Cansado, J.-Agrelo, D.-Villa, T. G. (1991): Effect of climatic conditions on yeast diversity in grape musts from Northwest Spain. American. Journal of Enology and Viticulture. 42: 141-144.

Miraglia, M.-Marvin, H. J. P.-Kleter, G. A.-Battilanic, P. (2009): Climate change and food safety: An emerging issue with special focus on Europe. Food and Chemical Toxicology. 47: 1009-1021.

Moriondo, M.-Orlandini, S.-Giuntoli, A.-Bindi, M. (2005): The effect of downy and powdery mildew on grapevine (Vitis vinifera L.) leaf gas exchange. Journal of Phytopathology. 153. 6: 350-357.

Pautasso, M.-Döring, T. F.-Garbelotto, M.-Pellis, L.-Jeger, M. J. (2012): Impacts of climate change on plant diseases - opinions and trends. European Journal of Plant Pathology. Springer online publishing.

Pearson, R.-Goheen, A. (1998). Compendium of Grape Diseases. $4^{\text {th }}$ print. APS Press. 9-11.

Pitt, J. I. (2000): Toxigenic fungi: which are important? Medical Mycology. 38. Suppl. 1: 17-22.

Pretorius, I. S.-Van der Westhuizen, T. J.-Augustyn, O. P. H. (1999): Yeast Biodiversity in Vineyards and Wineries and Its Importance to the South African Wine Industry. A Review. South African Journal for Enology and Viticulture. 20. 2: 61-70.
Rementeria, A.-Rodriguez, J. A.-Cadaval, A.-Amenabar, R. (2003) Yeast associated with spontaneous fermentations of white wines from the "Txakoli de Bizkaia" region (Basque Country, North Spain). International Journal of Food Microbiology. 86: 201-207.

Renouf, V.-Claisse, O.-Lonvaud-Funel, A. (2005): Understanding the microbial ecosystem on the grape berry surface through numeration and identification of yeast and bacteria. Australian Journal of Grape and Wine Research. 3: 316-327.

Romano, P.-Fiore, C.-Paraggio, M.-Caruso, M.-Capece, A. (2003) Function of yeast species and strains in wine flavor. International Journal of Food Microbiology. 86: 169-180

Sholberg, P.-Harlton, C.-Boulé, J.-Haag, P. (2006): Fungicide and clay treatments for control of powdery mildew influence wine grape microflora. HortScience. 41. 1: 176-182.

Szőke L. (szerk.) (1996): A szőlő növényvédelme. Mezőgazda Kiadó. Budapest. 137-138.

Tournas, V. H.-Katsoudas, E. (2005): Mould and yeast flora in fresh berries, grapes and citrus fruits.International Journal of Food Microbiology. 105: 11-17.

Viviani-Nauer, A.-Hoffmann-Boller, P.-Basler, P.-Gafner, J. (1995): Wild yeast flora on grapes of fungi disease resistant cultivars and their dynamics during fermentation. Schweizerische Zeitschrift fuer Obst-und Weinbau, Waedenswil. 131: 390-393. 